\title{
Respon struktur akibat perubahan jarak stiffener pada car deck Kapal Ferry Ro-Ro
}

\author{
Alamsyah $^{1^{*}}$, Septiany Tri Pangestu ${ }^{2}$, Amalia Ika Wulandari ${ }^{3}$ \\ 1,2,3 Teknik Perkapalan Institut Teknologi Kalimantan \\ Jl. Soekarno Hatta No.KM 15, Karang Joang, Kec. Balikpapan Utara, Kota Balikpapan, \\ Kalimantan Timur 76127, Indonesia \\ *Corresponding author: alamsyah@lecturer.itk.ac.id
}

\begin{abstract}
Ro-Ro type trans ships have a Car Deck which is useful for accommodating cargo in the form of vehicles. The construction of the deck must be strong enough so that it does not suffer structural damage when working with a certain load. In this case the stress strain becomes very important as an element of deck strength. As for what affects the strength of the deck construction, one of which is the stiffener distance. This purpose of research to determine the response of the car deck structure with variations in stiffener distance to the stress-strain value. The method used is the Finite Element Method. The results of detected the maximum stress value at a stiffener distance of $550 \mathrm{~mm} 325.471 \mathrm{~N} / \mathrm{mm}^{2}$ with a maximum strain of $3.33 \mathrm{x}$ $10^{-2} \mathrm{~mm}$, for a stiffener distance of $650 \mathrm{~mm}$ the maximum stress was $407.521 \mathrm{~N} / \mathrm{mm}^{2}$ and a maximum strain of $3.35 \times 10^{-2} \mathrm{~mm}$, a stiffener distance of $750 \mathrm{~mm}$ the maximum stress generated is $444.129 \mathrm{~N} / \mathrm{mm}^{2}$ with a maximum strain of $3.36 \times 10^{-3} \mathrm{~mm}$, a stiffener distance of $850 \mathrm{~mm}$, the maximum stress generated is $448.469 \mathrm{~N} / \mathrm{mm}^{2}$ with a maximum strain of $3.43 \times 10^{-}$ ${ }^{3} \mathrm{~mm}$. For a stiffener distance of $950 \mathrm{~mm}$, the maximum stress is $452.567 \mathrm{~N} / \mathrm{mm}^{2}$ with a maximum strain of $3.53 \times 10^{-3} \mathrm{~mm}$.
\end{abstract}

Keywords: Car deck, Finite Element, stiffener, stress-strain, Safety Factor.

\begin{abstract}
Abstrak
Kapal penyebrangan tipe Ro-Ro memiliki Car Deck yang berguna untuk menampung muatan berupa kendaraan. Konstruksi deck harus cukup kuat sehingga tidak mengalami kerusakan struktur jika bekerja dengan beban tertentu. Dalam hal ini tegangan regangan menjadi sangat penting sebagai unsur kekuatan deck. Adapun yang mempengaruhi kekuatan konstruksi deck, salah satunya adalah jarak stiffner. Penelitian ini bertujuan untuk mengetahui respon struktur car deck dengan variasi jarak stiffner terhadap nilai tegangan regangan. Metode yang digunakan yakni Finite Element Method. Hasil penelitian dideteksi nilai tegangan maximum pada jarak stiffener $550 \mathrm{~mm} 325.471 \mathrm{~N} / \mathrm{mm}^{2}$ dengan regangan maximum 3.33 x $10^{-}$ ${ }^{2} \mathrm{~mm}$, untuk jarak stiffener $650 \mathrm{~mm}$ dihasilkan tegangan maximum sebesar $407.521 \mathrm{~N} / \mathrm{mm}^{2}$ dan regangan maximum $3.35 \times 10^{-2} \mathrm{~mm}$, jarak stiffener $750 \mathrm{~mm}$ tegangan maximum yang dihasilkan sebesar $444.129 \mathrm{~N} / \mathrm{mm}^{2}$ dengan regangan maximum $3.36 \times 10^{-3} \mathrm{~mm}$, jarak stiffener $850 \mathrm{~mm}$ tegangan maximum yang dihasilkan sebesar $448.469 \mathrm{~N} / \mathrm{mm}^{2}$ dengan regangan maximum $3.43 \times 10^{-3} \mathrm{~mm}$. Untuk jarak stiffener $950 \mathrm{~mm}$ dihasilkan tegangan maximum yang sebesar $452.567 \mathrm{~N} / \mathrm{mm}^{2}$ dengan regangan maximum yang dihasilkan yaitu $3.53 \times 10^{-3} \mathrm{~mm}$.
\end{abstract} Kata kunci: Geladak kendaraan, FEM, Penegar, Tegangan-Regangan, Faktor Keamanan.

\section{Pendahuluan}

Ferry ro - ro merupakan salah satu alat transportasi penyebrangan pada negara kepulauan seperti Indonesia. Kapal ini digunakan mengangkut manusia dan kendaraannya. Pada deck kapal menerima beban yang cukup besar, mengharuskan kondisi kapal selalu dalam keadaan aman terutama dalam hal kekuatan konstruksinya. 
Kekuatan transversal kapal adalah kemampuan struktur melintang kapal untuk mempertahankan bentuk penampang kapal terhadap gangguan beban yang bekerja pada kapal seperti beban di geladak, beban di sisi, dan beban di bagian bawah. Sehingga terlihat jelas bahwa komponen utama struktur kapal adalah struktur bawah, struktur samping, dan struktur geladak [1]. Adapun yang mempengaruhi kekuatan konstruksi diantaranya, frame spacing, jarak stiffener, panjang tak ditumpu, tebal pelat dll.

Kekuatan normal struktur baja kapal memiliki titik leleh minimum dari REH 235 $\mathrm{N} / \mathrm{mm}^{2}$ dan kuat tarik Rm $400-520 \mathrm{~N} / \mathrm{mm}^{2}$ [2]. Untuk memenuhi tegangan yang diijinkan pada konstruksi maka dilakukan penambahan modulus konstruksi dengan meningkatkan ketebalan pelat atau menambahkan carling/longitudinal stiffner [3]. Untuk mampu menahan beban, maka suatu konstruksi pelat dilengkapi dengan stiffener untuk memperkokoh. Jarak penumpu mampu mempengaruhi kekuatan konstruksi, semakin rapat jarak penumpu maka semakin kokoh suatu konstruksi dan sebaliknya. Amalia et al menunjukkan penurunan beban berbanding terbalik dengan kenaikan frame spacing, semakin besar frame spacing maka semakin kecil beban yang dibutuhkan agar pelat mengalami deformasi [4]. Perubahan jarak penegar/gading akan berimbas pada kekuatan geladak kapal dalam menghadapi peristiwa buckling. Semakin besar jarak penegar/gading maka peluang pelat geladak mengalami tekuk besar dan sebaliknya [5].

Salah satu problem dalam konstruksi kapal yakni bagaimana mendesain konstruksi yang kuat, kokoh, dan tidak memerlukan material yang banyak (ringan). Dalm konteks kekinian peraturan konstruksi tidak mengatur jarak gading/penegar. Sehingga engineer kapal merencanakan kekuatan berdasarkan resiko deformasi yang berlebih pada konstruksi (yield point). Pada penelitian ini akan di simulasikan beberapa jarak stiffner pada geladak kendaraan kapal ferry ro-ro dan melihat respon struktur terhadap beban operasional kapal. Konstruksi akan ditinjau dari aspek safety factor.

Kapal Ferry Ro-Ro merupakan kapal yang beroperasi dengan penaganan muatan secara rolling it on and off pada single ramp atau series ramps. Ramps atau rampa dapat bekerja baik saat di kapal atau di dermaga. Untuk memaksimalkan proses bongkarmuat pada antar geladak menggunakan internal ramps. Kondisi tersebut mengambilalih spasi dari ruang muat [6]. Beberapa chiri khas dan keunikan Kapal Ferry Ro-Ro antara lain:

1. Mempunyai akses rampa pada bow, stern atau sisinya tetapi tidak harus semua rampa terdapat pada Ro-Ro;

2. Dilengkapi car deck dengan lajur yang yang panjang;

3. Ditemui banyak ventilator pada atas deck yang berguna sebagai srkulasi asap kendaraan saat dilakukan proses bongkar dan muat.

Car Deck adalah geladak kapal yang berfungsi sebagai tempat peletakan muatan berupa kendaraan, biasanya terdapat pada kapal ferry. Car Deck adalah komponen struktur konstruksi yang fital karena perannya yang tidak hanya untuk menampung muatan kendaraan namun juga menopang deck yang ada di atasnya [7].

Beberapa jenis Car Deck yakni :

1. Geladak kendaraan dengan sistem terpadu

2. Geladak kendaraan tanpa sistem terpadu

General arragement kapal Ferry RoRo ditunjukkan pada Gambar 1 [1].

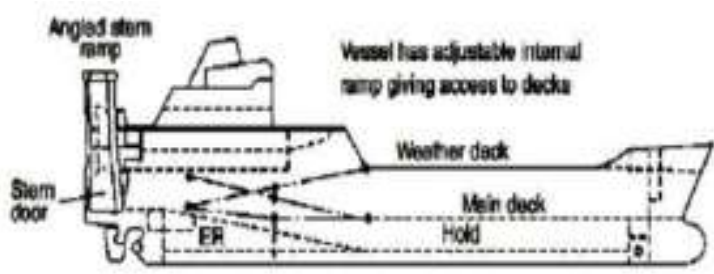

Gambar 1. General arragement [1]

Kapal Ferry Ro-Ro adalah kapal yang memiliki ciri-ciri dengan rasio $\mathrm{H} / \mathrm{B}$ relatif kecil yang bertujuan agar kendaraan 
mudah roll on dan roll off. Nilai rasio H/B yang relatif kecil menyebabkan momen inersia penampang midship relatif kecil yang membuat tegangan konstruksi pada pelat geladak cenderung besar pada kondisi perairan sagging dan hogging. Konsep ro-ro harus dilengkapi peralatan khusus seperti ramp dan elevator yang memudahkan proses bongkar-muat dari dan/atau ke kapal. Ramp digunakan pada pintu masuk kapal dan juga digunakan di dalam kapal untuk memberikan akses antar deck yang disebut Internal ramps. Jenis internal ramp ada yang bersifat tetap atau berengsel [6].

Salah satu cara menilai kekuatan konstruksi yakni dengan mengidentifikasi tegangan yang mungkin terjadi. Tegangan didefinisikan sebagai jumlah gaya yang bekerja per satuan luas. Ada dua jenis stress: stress normal dan tegangan geser. Tegangan normal $(\sigma)$ adalah ukuran gaya normal atau gaya aksial per satuan luas [8]. Ketika sebuah benda dikenai gaya, maka perbandingan antara besar gaya terhadap luas dimana gaya tersebut dikenakan disebut fenomena tegangan. Jika gaya yang dikenakan tegak lurus terhadap luas permukaan benda, maka fenomena tersebut adalah tegangan normal. Jika gaya yang dikenakan ke benda berarah tangensial terhadap permukaan benda maka fenomena tersebut adalah tegangan geser [8].

$$
\sigma=\frac{P}{A}
$$

dimana $\sigma=$ tegangan $(\mathrm{Pa}) ; F=$ gaya $(\mathrm{N}) ; A=$ luas penampang $\left(\mathrm{mm}^{2}\right)$. Sedangkan regangan (strain) diartikan sebagai perbandingan antara pertambahan panjang atau pendek batang dengan ukuran mulamula dinyatakan:

$$
\varepsilon=\frac{\Delta L}{L}
$$

dimana $\varepsilon=$ regangan $(\mathrm{mm}) ; \Delta L=$ pertambahan panjang $(\mathrm{mm}) ; L=$ panjang mula-mula ( $\mathrm{mm})$

Tegangan von mises disebut juga tegangan equivalent yang merupakan kombinasi beberapa jenis tegangan seperti tegangan normal $(\sigma)$ arah $\mathrm{x}, \mathrm{y}$, dan $\mathrm{z}$ serta tegangan geser $(\tau)$ yang bereaksi pada tempat tertentu. Jika tegangan von mises yang dihasilkan melebihi yield strength, maka material akan mengalami deformasi palstis, dan jika tegangan von mises yang dihasilkan melebihi ultimate strength maka akan pecah [9]. Tegangan von mises dapat ditentukan dengan persamaan sebagai berikut.

$$
\sigma_{v}=\sqrt{\sigma^{2}+3 \tau^{2}}
$$

dimana $\sigma$ adalah tegangan normal, $\tau$ adalah tegangan geser [10].

Setiap kali gaya diberikan pada suatu benda, gaya tersebut akan cenderung mengubah bentuk dan ukuran benda tersebut. Perubahan ini disebut sebagai deformasi, dan akan sangat terlihat jelas atau tidak terlihat secara kasat mata tergantung dari sifat fisik dari suatu benda. Misalnya, karet gelang akan mengalami deformasi yang sangat besar bila diregangkan, sedangkan konstruksi beton akan mengalami deformasi ringan akibat sering dilalui oleh kendaraan. Deformasi benda juga dapat terjadi akibat perubahan suhu. Contohnya ekspansi termal atau kontraksi atap yang disebabkan oleh cuaca [11].

Salah satu parameter yang digunakan dalam memastikan kemanan konstruksi yakni dengan mengidentifikasi Faktor keamanan (safety factor) konstruksi dimana faktor tersebut dapat diperoleh dengan membandingkan hasil tegangan kerja maksimum yang terjadi pada konstruksi dengan tegangan luluh material yang digunakan pada konstruksi. Untuk menghitung faktor keamanan digunakan persamaan berikut.

$$
S f=\frac{\sigma_{\text {yield }}}{\sigma_{\text {kerja } \max }}
$$

dimana $\sigma_{\text {yield }}$ adalah tegangan luluh material, $\sigma_{\text {kerjamax. }}$ adalah tegangan maximum yang bekerja pada struktur serta $\mathrm{SF}$ adalah safety factor (SF>1) [12]. Salah satu cara melihat keamanan konstruksi dengan mengamati nilai stress ratio yang diperoleh dengan membandingkan tegangan yang terjadi pada konstruksi akibat beban luar yang bekerja dan tegangan ijin material dimana nilai stress ratio harus bernilai lebih kecil dari $1(<1)[13]$. 
Salah satu metode yang digunakan untuk mengetahui nilai tegangan konstruksi yakni dengan menggunakan Metode Elemen Hingga dimana metode numerik yang lazim dalam menyelesaikan masalah teknis dan matematika pada suatu fenomena fisik. Jenis masalah fisika dan matematika yang memungkinkan diselesaikan menggunakan metode elemen hingga adalah analisis struktural dan non-struktural. Jenis masalah analisis struktur seperti analisa tegangan, analisa tekuk dan analisis getaran. Jenis analisis non-struktur seperti perpindahan panas dan massa, mekanika fluida, dan distribusi potensial listrik dan kemagnetan [14]. Dengan menggunakan $\mathrm{MEH}$, semua kompleksitas masalah dalam berbagai bentuk, kondisi batas, dan beban dapat dianalisa akan tetapi hasil yang diperoleh hanyalah perkiraan. Ini karena keragaman dan fleksibilitasnya sebagai alat analisis. Perkembangan cepat teknologi perangkat keras komputer dengan reduksi biaya membuat metode ini banyak digunakan karena komputer merupakan kebutuhan dasar untuk penerapan metode ini. Sejumlah aplikasi perangkat lunak analisis elemen hingga tersedia secara komersial untuk menyederhanakan analisis struktur yang kompleks pada berbagai kasus engineering [15].

\section{Metode Penelitian}

Kapal yang dijadikan objek penelitian kapal Ferri Ro-Ro 1320 GT. Data yang digunakan diantaranya adalah data main dimension dari kapal yang ditunjukkan pada Tabel 1.

Tabel 1. Data kapal ferry yang dijadikan objek penelitian

\begin{tabular}{ccc}
\hline No. & Particular & Ukuran \\
\hline 1 & Length over All (LoA) & $62.72 \mathrm{~m}$ \\
2 & Service Speed $($ Vs $)$ & $12 \mathrm{knot}$ \\
3 & Breadth $(\mathrm{B})$ & $15 \mathrm{~m}$ \\
4 & Height $(\mathrm{H})$ & $3.5 \mathrm{~m}$ \\
5 & Draft $(\mathrm{T})$ & $2.4 \mathrm{~m}$ \\
\hline
\end{tabular}

Selain data ukuran utama, diperlukan juga General arragement dan data konstruksi. Diperlukan penampang melintang yaitu midship section. Data tersebut ditunjukkan pada Gambar 2 dan 3.

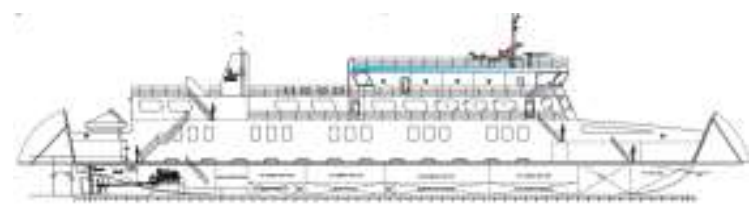

Gambar 2. General arragement Ferry Ro-ro 1320 GT.

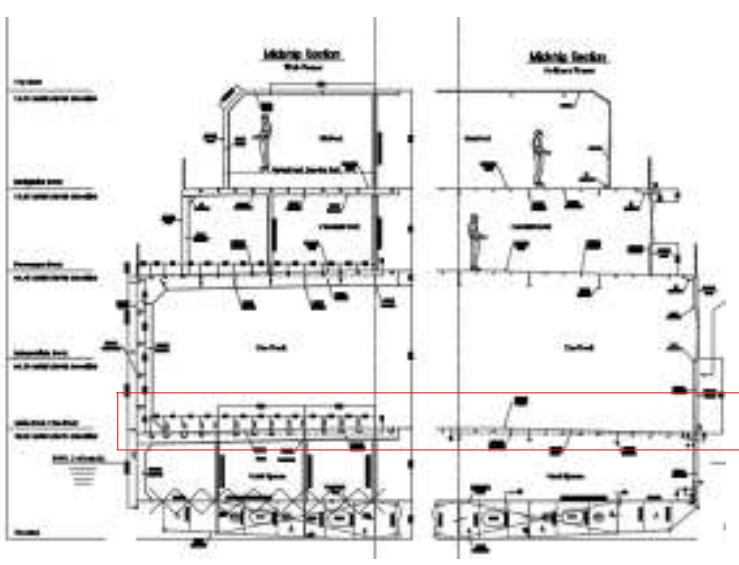

Gambar 3. Midship Section Ferry Ro-ro 1320 GT.

Untuk melengkapi data kapal ditampilkan juga data material yang digunakan pada konstruksi kapal yang ditunjukkan pada Tabel 2.

Tabel 2. Data Material ASTM A514

\begin{tabular}{|c|c|c|}
\hline No & Deskripsi & Ukuran \\
\hline 1 & Modulus Young & $210 \times 10^{3} \mathrm{~N} / \mathrm{mm}^{2}$ \\
\hline 2 & Yield Strength & $690 \mathrm{~N} / \mathrm{mm}^{2}$ \\
\hline 3 & $\begin{array}{l}\text { Ultimate Tensile } \\
\text { Strength }\end{array}$ & $938 \mathrm{~N} / \mathrm{mm}^{2}$ \\
\hline 4 & $\begin{array}{l}\text { Strain at rupture } \\
\text { (E max) }\end{array}$ & $63 \%$ \\
\hline
\end{tabular}

Gambar 3 selanjutnya dibuat model 3D menggunakan aplikasi berbasis FE dengan mengambil ukuran lebar kapal pada car deck kapal ferry ro - ro dan panjang model geladak kendaraan 5.5 m kemudian memvariasikan jarak stiffener yang ditunjukkan pada Gambar 4. 


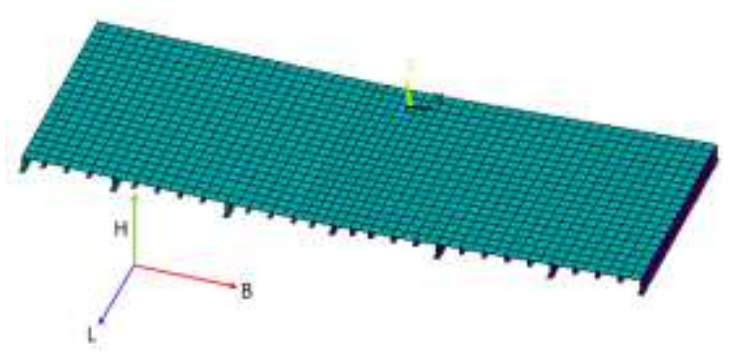

Gambar 4. 3D Car Deck Ferry Ro-Ro menggunakan FE

Selanjutnya dilakukan proses meshing pada model 3D car deck sebagai salah satu tahapan yang dilalui ketika menggunakan FE analisis. Ukuran mesh yang digunakan adalah $0.3 \mathrm{~m}$ dengan mesh type adalah hexahedron. Kondisi batas yang diberikan pada model car deck berupa tumpuan jepit, yang dalam FE dideteksi sebagai Fixed Support yang diberikan pada sekliling model car deck yang ditunjukkan pada Gambar 5. Beban yang diberikan berupa load pressure yang ditunjukkan pada Gambar 6.

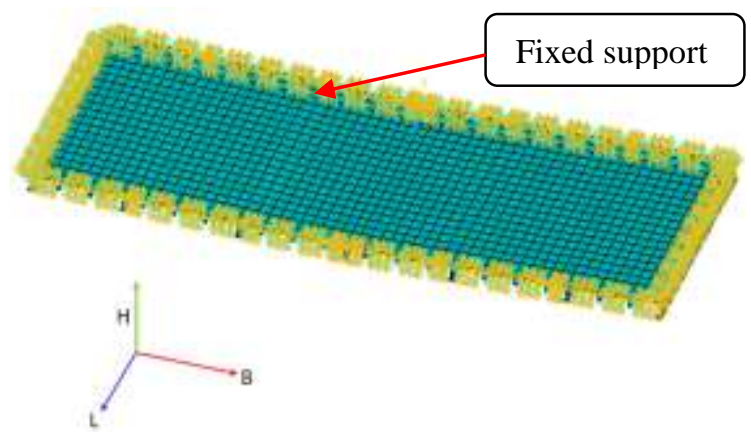

Gambar 5. Pemberian fixed support pada 3D Car Deck Ferry Ro-Ro

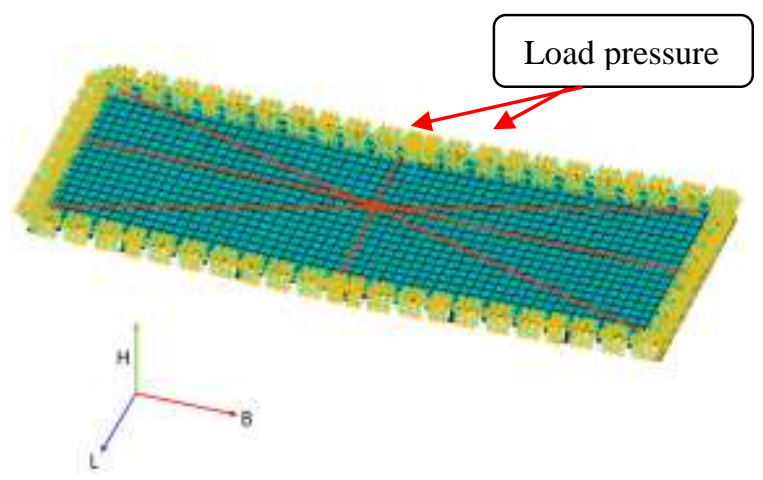

Gambar 6. Pemberian load pressure pada 3D Car Deck Ferry Ro-Ro.

Analisis dilakukan terhadap respon struktur konstruksi car deck yang terjadi akibat beban kendaraan yang disederhanakan dalam bentuk load pressure pada saat kapal beroperasi. Tahapan tersebut dilakukan untuk setiap variasi jarak stiffener masing-masing sebesar $550 \mathrm{~mm}, 650 \mathrm{~mm}$, $750 \mathrm{~mm}, 850 \mathrm{~mm}$, dan $950 \mathrm{~mm}$. Respon struktur dinilai dari tegangan equivalent dan regangan. Tegangan equivalent adalah tegangan maksimum von misses yang ditampilkan oleh metode FE setelah model 3D car deck di running. Tahap analisis akhir menilai keamanan konstruksi car deck dengan menggunakan pendekatan Safety Factor dan Stress ratio. Pendekatan tersebut membandingkan antara tegangan maksimum von misses dan tegangan luluh material konstruksi.

\section{Hasil dan Pembahasan}

Total kendaraan pada car deck dengan panjang $(\mathrm{L})=68000 \mathrm{~mm}$ dan lebar (B) $=15000 \mathrm{~mm}$ atau dengan luas $(\mathrm{A})=$ 1.020.000.000 $\mathrm{mm}^{2}$ yaitu berjumlah 10 unit bus dan 18 mobil sedan dengan berat @bus = 35 ton, @mobil sedan=1.6 ton. Maka berat kendaraan aktual yang berada pada car deck yaitu masing-masing (10 bus $\times 35$ ton) $=350$ ton dan $(18$ mobil sedan $\times 1.6$ ton $)=$ 28.8 ton, sehingga $\mathrm{F}_{\text {aktual }}=378.8$ ton. Untuk penyederhanaan kasus dan penyesuaian kemampuan PC penelitian, maka car deck dimodelkan dengan panjang $(\mathrm{L})=5500 \mathrm{~mm}$ dan lebar $(\mathrm{B})=15000 \mathrm{~mm}$ atau dengan luas (A) $=82.500 .000 \mathrm{~mm}^{2}$. Sehingga besar beban yang diinput pada model 3D car deck ditentukan dengan persamaan berikut :

$$
F_{\text {model }}=\frac{A_{\text {model }}}{A_{\text {Car deck actual }}} \times F_{\text {actual }}
$$

Sehingga didapatkan nilai beban yang diinput pada model $=30.63$ ton yang selanjutnya dikonversi dalam bentuk load pressure sebesar $0.00371372549 \mathrm{~N} / \mathrm{mm}^{2}$.

Adapun tegangan dalam kasus ini adalah ketika tegangan material pelat mencapai titik luluh yang diketahui sebagai yield strength. Tegangan von mises dijadikan patokan untuk memperkirakan keluluhan material terhadap pemberian beban pada objek dari hasil simulasi. Berikut hasil analisis FE terhadap struktur 
car deck berupa von misses stress. Untuk masing-masing jarak antar stiffener 550 $\mathrm{mm}, 650 \mathrm{~mm}, 750 \mathrm{~mm}, 850 \mathrm{~mm}$, dan 950 mm ditunjukkan pada Gambar 7, 8, 9, 10 dan 11.

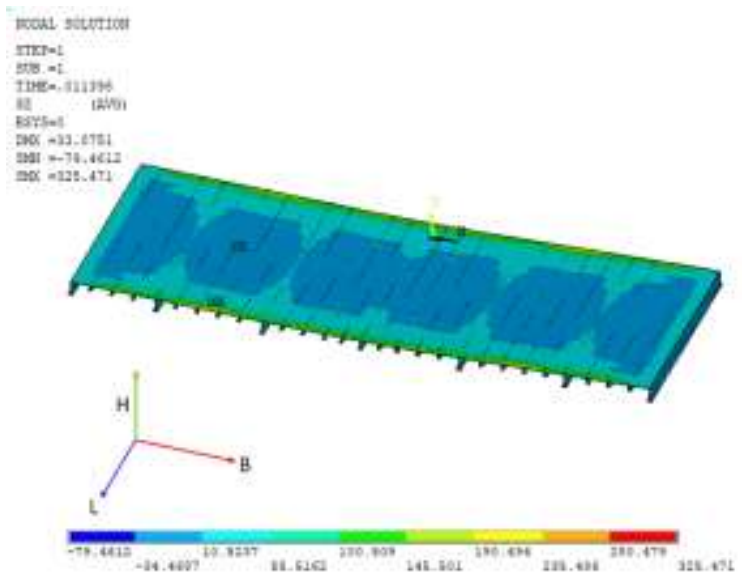

Gambar 7. Tegangan von mises pada jarak antar stiffener $550 \mathrm{~mm}$.

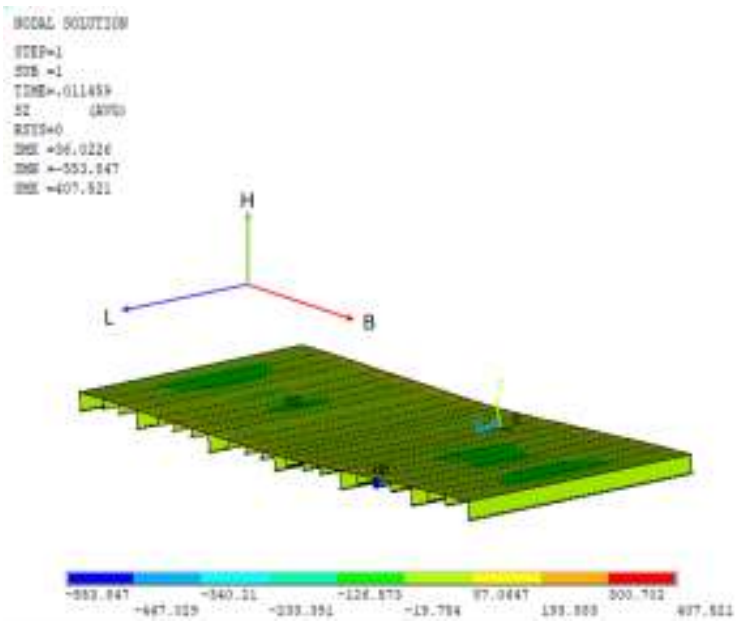

Gambar 8. Tegangan von mises pada jarak antar stiffener $650 \mathrm{~mm}$.
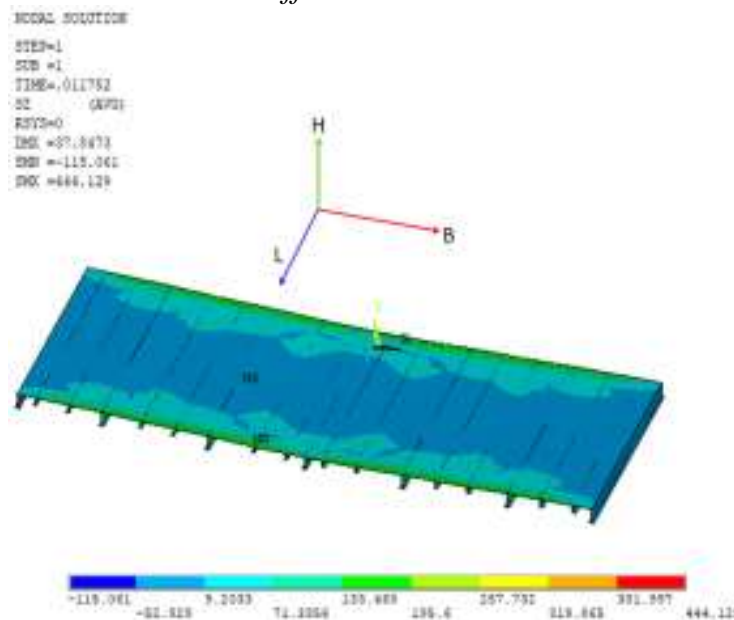

Gambar 9. Tegangan von mises pada jarak antar stiffener $750 \mathrm{~mm}$.

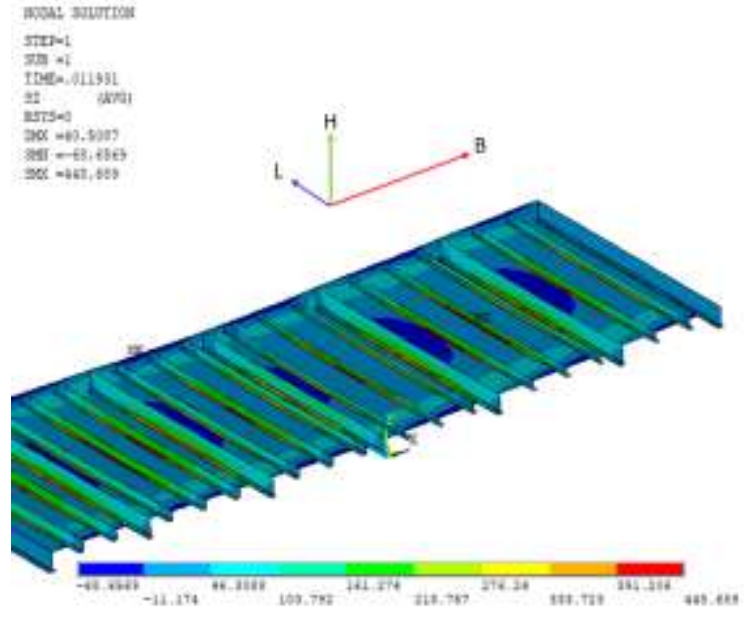

Gambar 10. Tegangan von mises pada jarak antar stiffener $850 \mathrm{~mm}$.

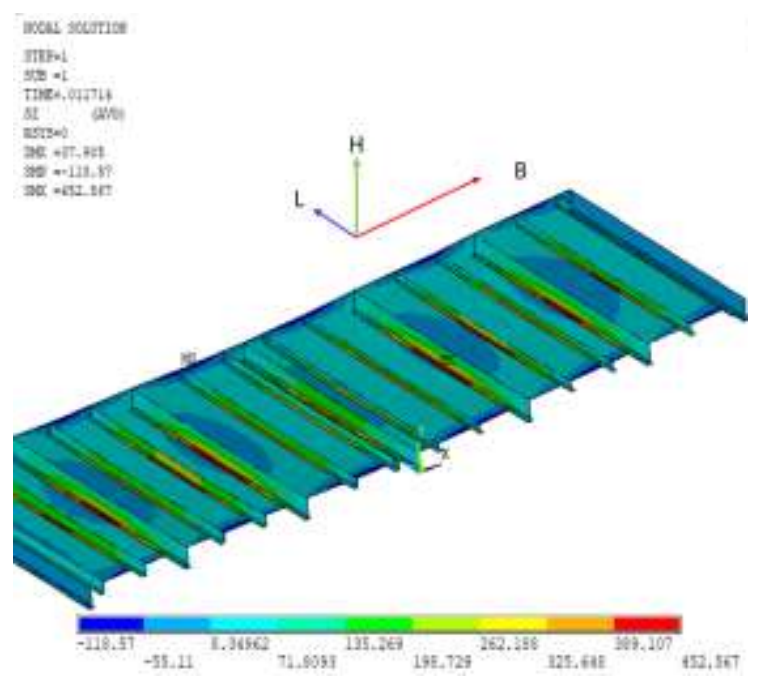

Gambar 11. Tegangan von mises pada jarak antar stiffener $950 \mathrm{~mm}$.

Gambar 7 menunjukkan jarak antar stiffener $550 \mathrm{~mm}$ terdeteksi tegangan maksimum von mises berada pada node 1250 sebesar $325.471 \mathrm{~N} / \mathrm{mm}^{2}$ dengan nilai regangan maksimum yaitu $3.33 \times 10^{-3} \mathrm{~mm}$. Gambar 8 menunjukkan jarak antar stiffener $650 \mathrm{~mm}$ terdeteksi tegangan maksimum von mises berada pada node 1221 sebesar $407.521 \mathrm{~N} / \mathrm{mm}^{2}$ dengan nilai regangan maksimum yaitu $3.35 \times 10^{-3} \mathrm{~mm}$. Gambar 9 menunjukkan jarak antar stiffener $750 \mathrm{~mm}$ terdeteksi tegangan maksimum von mises berada pada node 1262 sebesar 444.129 $\mathrm{N} / \mathrm{mm}^{2}$ dengan nilai regangan maksimum yaitu 3.36 x $10^{-2} \mathrm{~mm}$. Gambar 10 menunjukkan jarak antar stiffener $850 \mathrm{~mm}$ terdeteksi tegangan maksimum von mises berada pada node 1512 sebesar 448.689 
$\mathrm{N} / \mathrm{mm}^{2}$ dengan nilai regangan maksimum yaitu $3.43 \mathrm{x} 10^{-2} \mathrm{~mm}$. Gambar 11 menunjukkan jarak antar stiffener $950 \mathrm{~mm}$ terdeteksi tegangan maksimum von mises berada pada node 1350 sebesar 452.467 $\mathrm{N} / \mathrm{mm}^{2}$ dengan nilai regangan maksimum yaitu $3.52 \times 10^{-2} \mathrm{~mm}$.

Berdasarkan analisis didapat hasil tegangan-regangan yang bekerja pada setiap elemen-elemen pada struktur cardeck kapal ferry ro-ro, dengan mempertimbangkan kondisi syarat batas maka didapatkan kurva tegangan regangan untuk masing-masing jarak antar stiffener $550 \mathrm{~mm}, 650 \mathrm{~mm}, 750$ $\mathrm{mm}, \quad 850 \mathrm{~mm}$, dan $950 \mathrm{~mm}$ yang ditunjukkan pada Gambar 12.

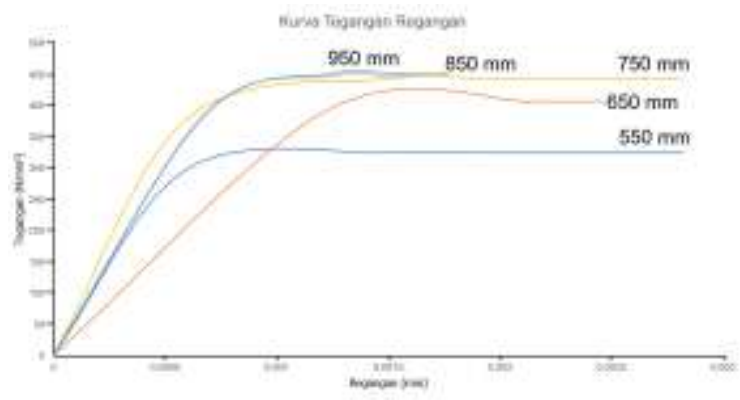

Gambar 12. kurva tegangan regangan.

Gambar 12 menampilkan kurva tegangan regangan stiffener $550 \mathrm{~mm}$ yang menunjukkan nilai tegangan $0 \mathrm{~N} / \mathrm{mm}^{2}$ sampai $280.479 \mathrm{~N} / \mathrm{mm}^{2}$, car deck masih linier dan selanjutnya sudah tidak linier. Konstruksi car deck kapal mencapai titik ultimate pada tegangan $325.471 \mathrm{~N} / \mathrm{mm}^{2}$ yang membuat sturktur mengalami deformasi. Kurva stiffener $650 \mathrm{~mm}$ yang menunjukkan nilai tegangan $0 \mathrm{~N} / \mathrm{mm}^{2}$ sampai $300.702 \mathrm{~N} / \mathrm{mm}^{2}$, car deck masih linier dan selanjutnya tidak linier. Konstruksi car deck kapal mencapai titik ultimate pada tegangan $407.521 \mathrm{~N} / \mathrm{mm}^{2}$ yang membuat sturktur mengalami deformasi. Kurva stiffener $750 \mathrm{~mm}$ yang menunjukkan nilai tegangan $0 \mathrm{~N} / \mathrm{mm}^{2}$ sampai $381.997 \mathrm{~N} / \mathrm{mm}^{2}$, car deck masih linier dan selanjutnya sudah tidak linier. Konstruksi car deck kapal mencapai titik ultimate pada tegangan $444.129 \mathrm{~N} / \mathrm{mm}^{2}$ yang membuat sturktur mengalami deformasi. Kurva stiffener $850 \mathrm{~mm}$ yang menunjukkan nilai tegangan $0 \mathrm{~N} / \mathrm{mm}^{2}$ sampai $391.206 \mathrm{~N} / \mathrm{mm}^{2}$, car deck masih linier dan selanjutnya sudah tidak linier. Konstruksi car deck kapal mencapai titik ultimate pada tegangan $448.689 \mathrm{~N} / \mathrm{mm}^{2}$ yang membuat sturktur mengalami deformasi. Kurva stiffener $950 \mathrm{~mm}$ yang menunjukkan nilai tegangan $0 \mathrm{~N} / \mathrm{mm}^{2}$ sampai $389.107 \mathrm{~N} / \mathrm{mm}^{2}$, car deck masih linier dan selanjutnya sudah tidak linier. Konstruksi car deck kapal mencapai titik ultimate pada tegangan $452.567 \mathrm{~N} / \mathrm{mm}^{2}$ telah mencapai tegangan ultimate yang membuat sturktur mengalami deformasi.

Faktor keamanan (safety factor) konstruksi bisa ditentukan dengan persamaan (4) yang ditunjukkan pada Tabel 3. Selain hal tersebut dilakukan juga pengamatan terhadap stress ratio yang terjadi pada konstruksi car deck.

Tabel 3. Safety Faktor dan stress ratio pada konstruksi car deck

\begin{tabular}{ccccc}
\hline \hline $\begin{array}{c}\text { Kondisi } \\
\text { jarak }\end{array}$ & $\begin{array}{c}\text { Yield } \\
\text { stress } \\
\text { Stiffener } \\
(\mathrm{mm})\end{array}$ & $\begin{array}{c}\text { Safety } \\
\text { Factor }\end{array}$ & $\begin{array}{c}\text { Stress } \\
\text { ratio }\end{array}$ & $\begin{array}{c}\text { Von mises } \\
\text { Stress } \\
(\mathrm{MPa})\end{array}$ \\
\hline 550 & 690 & 2.12 & 0.47 & 325.471 \\
650 & 690 & 1.69 & 0.59 & 407.521 \\
750 & 690 & 1.55 & 0.64 & 444.129 \\
850 & 690 & 1.53 & 0.65 & 448.689 \\
950 & 690 & 1.52 & 0.66 & 452.467 \\
\hline \hline
\end{tabular}

Tabel 3 menunjukkan jarak stiffener maksimum pada simulasi ini memiliki nilai safety factor yang terendah sebesar 1.52 sedangkan akan tetapi masih berada di atas 1. Sedangkan safety factor tertinggi terdapat pada jarak stiffener $550 \mathrm{~mm}$ sebesar 2.12. Secara keseluruhan untuk masing-masing jarak antar stiffener nilai safety factor berada di atas 1 ( $\mathrm{SF}>1)$. yang menandakan kondisi konstruksi car deck masih aman walaupun jarak antar stiffenernya di perbesar. Begitu juga dengan stress ratio dimana didetejsi nilainya berada di bawah $1 \quad(\mathrm{SR}<1)$ yang menjamin konstruksi car deck dalam keadaan aman.

\section{Kesimpulan}

Dari hasil simulasi variasi jarak antar stiffener pada penelitian kami 
menyimpulkan bahwa tegangan equivalen atau von mises stress yang terjadi pada konstruksi car deck masih dibawah tegangan luluh material. Nilai safety factor konstruksi berada di antara nilai $2.12 \sim 1.52$ yang menandakan bahwa kondisi konstruksi car deck masih aman walaupun jarak antar stiffenernya di perbesar. Begitu juga dengan stress ratio dimana dideteksi nilainya berada di bawah $1 \quad(\mathrm{SR}<1)$ yang menjamin konstruksi car deck dalam keadaan aman. Pada penelitian selanjutnya yang menggunakan metode FE sangat penting untuk melakukan konvergensi model atau sensitive mesh yang tidak dilakukan pada penelitian ini. Konvergensi model akan memberikan informasi size mesh yang tepat untuk digunakan pada model. Hal tersebut akan sangat mempengaruhi keakuratan hasil simulasi.

\section{Ucapan terimakasih}

Tim penulis memberikan apresiasi kepada Laboratorium Terpadu Institut Teknologi Kalimantan karena telah menfasilitasi penelitian ini. Terimakasih juga kepada LPPM Institut Teknologi Kalimantan karena telah memberikan motivasi dalam menyelesaikan penelitian yang dituangkan dalam bentuk paper. Dan terakhir kami berterimakasih kepada tim reviewer yang tidak kami ketahui namanya karena telah memberikan masukan positif dan kritik yang membangun sehingga paper ini layak dipublikasikan.

\section{Referensi}

[1] M. Shama, 2013, Buckling of Ship Structures. Egypt: Alexandria University.

[2] BKI, 2017, Rules for the classification and Construction. Part 1 Seagoing Ship.Volume V Rules for Materials. Jakarta: BKI.

[3] A. M. Nugraha, Hamzah, G. Sitepu, A. Ardianti, Ifhanuddin, and S. Baso, (2019) "Strength Behavior Analysis of Insert Plate for Placing Corner
Fitting due to Container Load," doi: 10.1088/1757-899X/875/1/012074.

[4] A. I. Wulandari, Nurmawati dan A. Dianiswara, (2019) "Buckling Analysis Deck Plate of Ferry RoRo," J. Wave, vol. 13, no. 1, pp. 1-6.

[5] O. F. Hughes and J. K. Paik., 2010, Ship structural analysis and design. New Jersey: Society of Naval Architects and Marine Engineers (SNAME).

[6] T. Lamb, 2003, Ship Design and Construction. New Jersey: Society of Naval Architects and Marine Engineers (SNAME).

[7] A. Mukhsin, I. P. Mulyatno, dan S. J. Sisworo, (2016) "Analisa Kekuatan Konstruksi Car Deck Akibat Penambahan Deck Pada Ruang Muat Kapal Motor Zaisan Star 411 Dwt Dengan Metode Elemen Hingga," $J$. Tek. Perkapalan, vol. 4, no. 2, pp. 341-351.

[8] S. Patnaik and D. Hopkins, 2004, Strength of Materials. Amsterdam: Elsevier.

[9] I. A. of C. S. (IACS), 2014, Common structural rules for double hull oil tanker.

[10] BKI, 2014, Rules For The Classification and Construction Seagoing Ship, Volume II. Jakarta: BKI.

[11] R. C. Hibbeler, 2018, Mechanics of Materials in SI Units, 10th ed. Pearson..

[12] I. P. Mulyatno, A. Trimulyono dan S. F. Khristyson, (2014) "Analisa Kekuatan Konstruksi Internal Ramp Sistem Steel Wire Rope Pada Km. Dharma Kencana Viii Dengan Metode Elemen Hingga," Kapal, vol. 2, no. 3, pp. 85-92, doi: 10.14710/kpl.v11i2.7267.

[13] R.Munandar, A. Ardianti, G. Sitepu, A.M. Nugraha, Hamzah and M.I. Hayatuddin, (2019) "Study on Transverse Strength of the DeckContainer Ships Due to Laying All 
Containers on Deck," EPI Int. J.

Eng., vol. 2, no. 2, pp. 178-184, doi: 10.25042/epi-ije.082019.14.

[14] Y. Susatio, 2004, Basics of Finite Element Method. Yogyakarta: ANDI.

[15] S. Bhavikatti, 2005, Finite Element Analysis. New Delhi: New age International Publisher. 